\title{
The Local Wisdoms in Bahasa Indonesia Text Books in a Primary Class: Ethnopedagogy Study
}

\author{
I.W. Rasna ${ }^{1}$, D.K. Tantra ${ }^{2}$ \\ Faculty of Language and Arts \\ Universitas Pendidikan Ganesha \\ Singaraja, Bali \\ wayanrasna@ymail.com ${ }^{1}$,dewatantra@yahoo.com²
}

\begin{abstract}
This study aimed at producing an integrated thematic book in terms of Indonesian Language and Literature for grades I and II with local Balinese wisdoms. Therefore, in year 1, exploration of themes / subthemes of the materials were conducted. In year 2, the draft plan was developed into a draft of the book. In year 3, the draft of the book was tested from the validity of experts, content, design, and media. Users' responses were based on field testing. The methods of data collection were questionnaire, observation, interview, and test. The results showed that: (1) integrated thematic book with sustainable local of Bali was qualified as a textbook. (2) The validity (experts, content, design, and media) was qualified as valid. Students' understanding valued 75 (good). Thus, this thematic book was qualified as teaching materials.
\end{abstract}

Keywords—language; Indonesia; local wisdom; ethnopedagogy

\section{INTRODUCTION}

Approaches should result good characters, but on the contrary, they create people with bad behaviors [1], [2]. Lickona [3] mentions that 1) the moral of our society is not strong; 2) many members of societies live a less moral life than they once had that are characterized by a) a moral decline in attitudes and behavior; b) a sexual behavior; c) a bad language (impolite); and a brutal and vulgar media culture. This is proven by the ISIS movement that changed the world and claimed the death toll through terror bombing in France in 2015 and the bomb terror of Jakarta on January 14, 2016 [4]. This shows that modern knowledge merely conferred on past welfare, which prompted humans to pursue temporal satisfaction, but was unable to resist the appetite of conforming to the 'chaotic' condition as what was written in Kompas in an article entitled Mortifying Moral Damage, it was stated that during 2004-2011 Kemdagri recorded that 158 regional heads (governors, regents, mayors) were involved in corruption [5]. During 2008-2011, 42 DPR members were involved in corruption. Cases of corruption occurred in a number of institutions such as KPU, judicial commissions, KPPU, General Directorate of Tax, and Bank Indonesia. Based on this, the aims of this research were 1) to develop a draft of an integrated thematic book in order to fulfill the requirement as a teaching material 2) to fulfill the validity requirement (expert, content, design, and media). It was important to reduce these adverse effects.

The world of education cannot be separated from cheating such as cheating by students in the form of exam cheating and cheating by lecturers in the form of plagiarism. In [5], it is mentioned that plagiarism occurred in several universities, they were, Bandung, Gorontalo, Yogyakarta, and Jakarta. Academicians' plagiarism and students' cheating are identical to corruption [6].

The scrutiny of the current state inspired the researcher to flash back to the past, which is traditional knowledge. The traditional knowledge, although it is not systematic and had not been studied with scientific systems, but empirically proven for centuries to have organized the community with its cultural attributes nicely and regularly related to astrology, agriculture, religious, socio-cultural, traditional health as recognized nowadays [7]. This means that western knowledge is not always better and or better suited than eastern knowledge. Because knowledge based on western cultures was different from eastern cultures. As a result, there is a cultural conflict in students' learning. Therefore, learning needs to be based on local cultures / local wisdoms through Ethnopedagogy, because the cultural incompatibility was resulted in conflicts [8], [9], [10].

There is something substantial that need to be examined in terms of formal education system. The formal education system of Indonesia tends to follow the curriculum developed in the western countries. Western education tradition views education as a subculture. Therefore, education will determine the development of the cultures. Indonesia, which used the western education system, will automatically incorporate western cultures in Indonesia's education system. This was where conflicts arouse not only from the theoretical cultures, conflicts would also happen in learning, democracy, drugs, sex, and so on.

According to [11], different students' cultural backgrounds become a problem for students to understand western science. In line with this, Suparman [12] also reveals that there is a socio-cultural linkage to students' learning. Therefore, the 
need for alignment should be done, between the traditional knowledge (local wisdom) with the modern knowledge [13]. If this alignment led to a harmonious learning, then the teaching of knowledge would reinforce the learning outlook about nature [14]. This indicates the opening of opportunities to integrate local wisdoms in education both related to sociology, geography, cultures, Ethnopedagogy, and psychology [15].

The availability of textbooks in elementary schools, containing Balinese science and the pedagogy context of Catur Pramana is high [16]. This high level of accessibility indicates the importance of socio-cultural, religious sociology, and religious psychology. Therefore, psychology, especially the psychology of education becomes one of the contributions of the material selection [17]. Materials as learning discourse are related to achievement. Achievement begins with the accommodation relationship between the communication structure and the structure of science. Discourse in the context of science production needs to be oriented to the structure of science. Chapter structure of science based on writing should be centered on the pedagogical explanation of textbooks to be matched with the ability of readers [18]. Teachers are not given too many tasks, except reading books [19].

Matching pedagogical explanation of textbooks with readers' ability needs to be done/ arranged to support learning activities [20], [21]. Therefore, valid learning tools such as books should be paid attention. Therefore, the validity of the book affects the cognitive and affective learners [22]. The effect of validity towards affective learners shows the value of a character in the formation of personality [23], [24]. Therefore, the preparation of learning tools, particularly textbooks, becomes important in the efforts to optimize learning services. This service is important because it will affect the politeness, including language politeness [25]. Modesty is integral to the character. Character education is delivered and integrated into every subject. This integration can support effective learning [26]. This means that teaching was done in a multidisciplinary approach [27]. This approach benefitted that education was done without reducing the time of delivering the materials. As the impact, there is an influence of character education on self-esteem and personality progress [28]. Self-esteem and personality progress were the individual motivations that influenced students' response. Students' response, in this case, elementary school students, grades I and II had a positive motivation to the course of research [29]. A negative response was the source of bias so that it influenced the interpretation [30]. Beyond that, motivation also affected the response [31].

\section{METHOD}

Regarding with the purpose, the focus of this study was to develop an integrated thematic book in terms of Indonesian Language and Literature for grades I and II with local Balinese wisdoms. In order to accomplish this goal, there were some processes conducted: 1) validity of experts from the contents, the sequence of the materials which were based on local Balinese wisdoms, 2) teachers' responses, students' responses, and 3) the revision of the textbook based on the experts' judgments, teachers, and students in order to be implemented as teaching materials. In the year 1, defining and designing the textbook had been conducted. In the year 2 , the development of the textbook had been conducted and in the last year (in 2017), the evaluation had been conducted.

The evaluation was in the form of formative evaluation. It was conducted in the end of teaching and learning process in March and April 2017. Every week, the teachers were given questionnaires and students were observed as the test of evaluation. The purpose of this process was to provide suggestions or recommendations on the weaknesses of the textbook. The result of the questionnaires and observation were discussed and reviewed by the team as the basic process on developing the revision of the textbook.

The subject of this research were students and teachers of grades I and II in Bali, which comprised of 4 elementary schools in Buleleng, 4 elementary schools in Klungkung, 4 elementary schools in Denpasar, and 4 elementary schools in Tabanan. The samples of the teachers were 8 and the samples of the students were 8 classes in every regency. Thus, the total samples of the teachers in Bali were 32 (teachers for grade I and II) and the total of the students' sample was 32 classes (students of grade I and II). The object of this study was an integrated thematic book in terms of Indonesian Language and Literature for grades I and II with local Balinese wisdoms.

The textbook was tested from the validity of content, design, and media. In this stage, the process of validation was validated by the experts of Indonesian Language and Literature. Meanwhile the validation of design and media was validated by experts in those fields. The users' response was conducted by the teachers and the students of grade I and II in Bali. To get the users' responses, the researcher conducted the test in small scale in one of the school in Bali, SD Lab Singaraja Undiksha. Meanwhile, the test for the big scale was conducted in all school samples in Bali.

The method of data collection is based on the types of the data needed. The obtained data, which have been validated (content, design, and media) were collected through questionnaire and observation. The teachers' responses were collected through questionnaire meanwhile students' responses were collected through observation. The test was used to assess students' comprehension.

The obtained data from the teachers' questionnaire and students' observation during the learning process were analyzed by descriptive qualitative analysis. The validated data, therefore, were analyzed using descriptive statistics.

\section{FINDINGS AND DISCUSSION}

\section{A. The Review of Teaching Materials with Local Balinese Wisdoms}

The result of the validity from teaching materials with local Balinese Wisdom was 3.1 (valid). The validity of this result could be accomplished because in the first year, the development of the textbook with its literature review had 
been selected and described into narrative, descriptive and exposition text. After that, the texts had been illustrated in pictures. Based on the pictures provided in the textbook, then students were asked to tell the text orally as the aspect of speaking skill. The selection and the classification of the vocabulary and language structure in the books aimed at introducing the lexical, grammatical, and 4 major aspects in Bahasa Indonesia, namely, listening, speaking, reading and writing for the students. This book also intended to foster students' understanding toward the materials.

The texts that had been created were selected and arranged on their subthemes of character education based on the core competencies, basic competencies, indicator and the instructional objectives. In line with this statement, the researcher had arranged the themes, subthemes, core competency, basic competency, indicator, subthemes combined with the first draft until the final draft systematically and logically with the insertion of the local Balinese wisdoms in order to be clear. These can be seen briefly in table 1 and table 2 as follows.

TABLE 1. THEME/SUBTHEMES,CORE COMPETENCY AND BASIC COMPETENCY IN BAHASA INDONESIA FOR GRADE I AND II

\begin{tabular}{|c|c|c|c|}
\hline $\begin{array}{l}\text { Class } \\
\text { Smt } \\
\text { (1) }\end{array}$ & $\begin{array}{l}\text { Theme/ } \\
\text { themes of } \\
\text { local } \\
\text { Balinese } \\
\text { Wisdoms } \\
\text { (2) }\end{array}$ & Subthemes & Core Competency \\
\hline $1 / 1$ & $\begin{array}{l}\text { Theme 1: } \\
\text { Myself/ } \\
\text { Atman } \\
\text { Budhi } \\
\text { Manah } \\
\text { Indria }\end{array}$ & $\begin{array}{l}\text { Subtheme } \\
\text { 1: My New } \\
\text { Friends and } \\
\text { I }\end{array}$ & $\begin{array}{l}\text { 1. Appreciating and practicing the } \\
\text { religious value that students are } \\
\text { following } \\
\text { 2. Appreciating and practicing } \\
\text { honest behavior, discipline, } \\
\text { responsibility, caring and feeling } \\
\text { confident in interacting with family, } \\
\text { friends, and teachers. }\end{array}$ \\
\hline
\end{tabular}

TABLE 2. BASIC COMPETENCY, INDICATORS, SUBTHEMES OF LOCAL BALINESE WISDOMS, AND SOURCES OF LOCAL BALINESE WISDOMS IN BAHASA INDONESIA FOR GRADE I AND II

\begin{tabular}{|c|c|c|c|}
\hline $\begin{array}{c}\text { Basic } \\
\text { Competency } \\
(5)\end{array}$ & $\begin{array}{c}\text { Indicators } \\
\\
(6) \\
\end{array}$ & $\begin{array}{c}\text { Subthemes of } \\
\text { Local } \\
\text { Balinese } \\
\text { Wisdoms } \\
(7)\end{array}$ & $\begin{array}{l}\text { Sources of } \\
\text { Local Balinese } \\
\text { Wisdoms } \\
(8) \\
\end{array}$ \\
\hline $\begin{array}{l}\text { 1.1. Being } \\
\text { grateful to } \\
\text { the } \\
\text { opportunity } \\
\text { to learn } \\
\text { Bahasa } \\
\text { Indonesia as } \\
\text { a medium of } \\
\text { national } \\
\text { communicati } \\
\text { on. }\end{array}$ & $\begin{array}{l}\text { - Identifying the } \\
\text { steps of introducing } \\
\text { self. } \\
\text { - Introducing self by } \\
\text { stating the complete } \\
\text { name. } \\
\text { - Introducing self by } \\
\text { stating the nick } \\
\text { name. } \\
\text { Mentioning friends' } \\
\text { names. }\end{array}$ & $\begin{array}{c}\text { Purusa dan } \\
\text { pradana }\end{array}$ & $\begin{array}{l}\text { Theme: } \\
\text { Bhagawad gita } \\
\text { III. } 42 \text { and } \\
\text { Kathalepanisa } \\
\text { d 1.3.3-4 } \\
\text { Subtheme:Bha } \\
\text { gawad Gita } \\
\text { XIII. } 23\end{array}$ \\
\hline
\end{tabular}

Based on the table 1 and table 2, it can be seen the relationship among column (1), (2), (3), (4), (5), (6), (7), and
(8). Those are related to each other. Theme/ subthemes, core competency, basic competency, indicator, subthemes of local Balinese wisdoms and the sources of local Balinese wisdoms in Bahasa Indonesia for grade I and II had been developed as the book plan of character education with the insertion of local Balinese wisdoms.

\section{B. The Validity of Teaching Materials}

The validity of the book could be seen from: a) Content validity including: 1) the structure which consists of (a) the appearance was 3.1 (valid), and (b) the organization was 3.2 (valid). 2) The material which consists of (a) the relation between materials and local Balinese wisdoms was 3.3; (b) the suitability among material, basic competency, and indicator 3.2 ; (c) the clarity was 3.1 ; (d) The attractiveness was 3.2 ; (e) The level of difficulty 3.2; (f) Ethnopedagogy was 3.5; (g) eco-pedagogy was 3.5; (h) the relevance with character education 3.5; (i) The integration of character values in the textbook was 3.5 ; 3) language consists of : a) The language used in textbook was 3.5 ; b) age compatibility was 3.5.

Based on the explanation above, it can be seen that the content validity had been examined in accordance to (1) structure; (2) materials; and (3) language in order to be qualified as teaching materials. This integrated book was qualified as teaching materials because first, the process of composing the sentence structure was based on the findings of students' sentence structure in a low class (grade I and II in elementary school). The organization of the language structure of the book was based on the students' language structure. Thus, it can enhance the effectiveness of communication in the process of learning. The second one, the insertion of local Balinese wisdoms in the teaching materials was suitable with the local culture of the students so that it can foster students' understanding and strengthen the reliability of the teaching materials. The continuity of the materials with students' culture is not only beneficial for enhancing students' understanding, but also to make cultural endurance from the era globalization. Moreover, the language used in the book was qualified as valid because the vocabulary used fitted with students' vocabulary. It was based on the local Balinese wisdoms of the students' culture (Ethnopedagogy) and from the students' environment (eco-pedagogy).

The validity of design comprises of cover's format including: a) Attractiveness was 3.2 (valid); b) the adjustment of color and cover image was 3.3 (valid); c) the font and its use was 3.4 (for grade I and II); d) image feasibility was 3.4; e) the relevance of the pictures with local Balinese wisdom was 3.4 (Ethnopedagogy); (f) the relevance of the pictures with the environment was 3.4 (eco-pedagogy). In this case, design and media are closely related to each other, thus those had been integrated as one packaged. The validity of the design and media had been examined based on the sequence of the draft plan with the local Balinese wisdom in accordance with the culture and environment.

Matching students' culture with the teaching materials, design, and media had provided the suitable pictures of 
students' culture in the book. The suitability of environment also had provided appropriate teaching materials, design, and media with the environment of the students (eco-pedagogy).

The insertion of local Balinese wisdoms that covers students' culture (Ethnopedagogy) and students' environment (eco-pedagogy) in teaching materials is not only beneficial for the students and teachers, but the outcomes will also give positive long-term impacts for the society and governments. It is because the mental revolution was done through the implementation of character education in an integrated thematic book sustainable ethno-eco-pedagogy.

\section{The review of users' responses}

\section{1) Teachers' responses}

The teachers' responses towards an integrated thematic book for grades I and II were: First, the material of "semutsemut api" with its meaning was not suitable for students in a lower grade. It was hard for students in their age to understand the meaning of that song. Nonetheless, it will be good if the meaning of this song is inserted in teachers' book, but not on students' book. Therefore, it is suggested that the material "semut-semut api" concerns more in the aspects of its lexical, grammatical, and the speaking skills. Thus, the revision was only on the meaning of the story "semut-semut api" from students' book.

Moreover, the exercises in the book should match with the time allotment of some materials that should be learnt by the students. However, after providing the explanation to the teachers that the exercises were not done in the school only, but also done by in students' as their practice at home.

The teachers' responses on the insertion of local wisdom in national curriculum were good. The correlation of local wisdom inserted in teaching materials make teachers easier to teach the students and the students were easier to understand the concept of the materials because it is closely related with their culture and their environment. It fosters the students in the process of learning and makes students more responsive in the process of learning. Therefore, it is suggested that the integrated thematic book with local Balinese wisdoms can be developed more for grades III-VI.

\section{2) Students' responses}

Students were so enthusiastic in the process of learning either for the design, the pictures, and the materials given by the teachers. They were actively involved in the process of learning and showed good response towards the materials given by the teachers. Students were full of pep in answering teachers' question or answering the task given by the teachers.

\section{CONCLUSION AND SUGGESTION}

- This research showed that it was easier for students to study if the learning was done according to the cultural background of the students themselves (Etnopedadogy), which was different from the learning that was conducted conventionally by treating the materials for all students with different backgrounds alike. For instance, Balinese students had no backgrounds about trains which made the materials about trains abstract, but it was different in case of Legong dance. It was because Legong dance was a part of their cultures so it made them easier to understand.

- The process of learning became easier and simpler in this learning compared to the previous one, because besides using etnopedagogical approach, ecopedagogy was also used that was students learned through the environment surrounding them. For example, Balinese students would learn easier with the condition, which was like their environment in Bali, compared to when they had to study with an environment that did not resemble their native environment such as the flora and the fauna. Balinese students would recognize dogs faster than elephants and tigers.

- The choice of words played an important role in the learning process. It was because the words used in creating the book for grades I and II were the words from the result of the previous year.

- The materials arranged were based on the cognitive development of students grades I and II, so it was easier for them to understand the materials.

- The collaboration of the points (1) - (8) in arranging the materials enabled students to understand the materials better.

Thus, an integrated thematic book with local Balinese Wisdom for grade I and II was qualified as teaching materials. The validity (experts, content, design, and media) was qualified as valid (3.1) and users' responses valued $\geq 70$ (good). Those can be reached, because the teaching materials were integrated with local Balinese wisdom, which is closely related with students' environment (eco-pedagogy) and students' culture (Ethnopedagogy). Thus, it is suggested that the teaching materials were integrated with ecoEthnopedagogy.

\section{REFERENCES}

[1] F. Mu'in, Pendidikan Karacter Konstruksi Teoritik dan Praktik. Yogyakarta: : AZ-Ruzz Media, 2011.

[2] K. Sandika, "Membentuk Siswa Berkarakter Mulia Melalui Pola Pembelajaraan," Unpublished, 2014.

[3] T. Lickona, "Character Matters: How to Help Our Children Develop Good Judgment, Integrity, and Other Essential Virtues," Transl. J. A. Wamago and J. A. R. Zien. Jakarta: PT Bumi Aksara, 2012.

[4] Bali Post, "Teror Bom Jakarta," p.1 , 2016.

[5] Kompas, "Kerusakan Moral Mencemaskan", p. 1, 2011.

[6] M. Samani and Hariyanto, Konsep dan Model Pendidikan Karakter. Bandung: Remaja Rosdakarya, 2005

[7] Z. Daulay, Pengetahuan Tradisional: Konsep, Dasar Hukum, dan Praktiknya. Jakarta: PT Raja Grafindo Persada, 2011.

[8] I. W. Subagia, "Science Education and Cultural Clash: A Case Analysis of Science Education in Bali", in Postgraduate Student Conference, Graduate School of Education, La Trobe University., 1999.

[9] O. Jegede and P. Okebukola, "Influence of Sociocultural factor on Secondary Students Attitude toward Science", Research in Science Education, vol. 19, pp. 150-160, 1989. 
[10] O. Jegede, "Collateral Learning and the Eco-cultural Paradigm Science and Matematics Education in Africa", Studies in Science Education, vol. 25, pp. 80-140, 1995.

[11] O. Jegede and G. Aikenhead, "Trancending Cultural Borders: implication for Science Teaching.", 2002. [Online]. Available: http://www.oukk.edu.hk/cridal/misc/jegede.htm. [Accessed: 01- Jun2002].

[12] Suparman, et al, "Keterkaitan Sosiokultural Anak Didik" in Penyedian Materi Pokok Buku Ajar Ketrarampilan Membaca Bahasa, 1990.

[13] W. B. Stanley, and N.M. Brickhouse, "The Multicultural Question Revisited". Science Education, vol. 85, no. 1, pp. 35-48, 2001.

[14] W. Cobern and G. Aikenhead, "Cultural Aspects of Learning Science", 1996. [Online]. Available: http://wmich.edu/slcsp/121htm. [Accessed: 01- Jan- 2000].

[15] M. Muslich, KTSP: Pembelajaran Berbasis Kompetensi dan Kontestual, Jakarta: Bumi Aksara, 2007.

[16] W. Suja and M. Wirta, "Implementasi Buku Ajar Bermuatan Konten Sains Asli Bali dan Konteks Pedagogi Catur Pramana.", Jurnal Pendidikan dan Pengajaran., vol. 45, no. 2, 2002.

[17] H. Jalaludin, Psikologi Agama, Jakarta: PT Raja Grafindo Persada, 2005.

[18] Siregar, "Studi Penerapan Pedagogi Materi Subjek dalam Penulisan Buku Teks MiPA untuk mengembangkan ketrampilan intellectual Mahasiswa FMIPA IKIP Badung," Tesis FMIPA IKIP Bandung, 2013.

[19] A. Suryadi, and H.A.R. Tilaar, "Analysis Kebijakan Pendidikan," Bandung: Remaja Rosda Karya, 1993.

[20] S. Chodijah, "Pengembangan perangkat pembelajaran Fisika model guided inquiry dilengkapi dengan penilaian portofolio pada materi gerak melingkar", Penelitian Pembelajaran Fisika, vol. 20, p. 1, 2012.

[21] I. W Rasna, et al, "Studi Eksprementasi dan Penelusuran Model Buku Ajar yang Relevan Dengan Perkembangan Kemampuan Berpikir Anak Usia SD: Studi Antisipasi Kesenjangan Kemampuan Berpikir dengan Tingkat Keterbacaan Buku Ajar," Laporan Penelitian Ditbinlitabmas Dirjen Dikti Depdekbud, Singaraja: STIKP, 2000.

[22] L. Lala, P. Andreas and E. Cahyono, "Pengembangan Perangkat Pembelajaran Biologi berbasis kasus dan berorientasi Pendidikan Karakter", Journal of Innovative Science Education, JISE, vol. 2, no. 1, pp. 1-5, 2013.
[23] M.H. Zakaria, "Character Building in ESL Materials: Value and Malaysian English Curriculum," Journal Social Sciences, vol. 65, no. 2, pp. 42-44, 2013

[24] E. Kristanti and S. Rildo, "Pengembangan Perangkat Pembelajaran Bioentrepreneurship Pembuatan Makanan dari Limbah cair Pengolahan Kedelai.", Journal of Innovative Science Education, JISE, vol. 21, no. 1, pp. 110-120, 2012.

[25] E. Sulatriana, "Pengaruh Sikap Bahasa Terhadap Kesantunan Berbahasa Mahasiswa IKIP PGRI Pontianak.", Journal Pendidikan Bahasa, vol. 4, no. 1, pp. 70-85, 2015.

[26] S. Sodiq, "Developing Language Learning Textbooks Enriched with Sense of Literacy: The Case of Junior High School in Indonesia", International Journal of Education Studies, vol. 8, no. 9, pp. 118-126, 2015.

[27] M. Adeyemi, T. Moumakwa and D. Adeninhun, "Teaching Character Education Across the Curriculum and the Role of Stakeholders at Junior Secondary Level in Bostwana", International Study Home Community, Sci., vol. 3, pp. 95-105, 2009.

[28] A. Tannui, and A. At Hroub, "Effect of Character Education on the Self Esteem on Intellectually able an lessable elementary students in Kuwait," International Journal of Special Education, vol. 28, no 1, pp. 45-60, 2013.

[29] W. Widhiarso, "Deteksi dan Eksplorasi Kesesatan Respon Siswa pada Skala Motivasi Berprestasi," Jurnal Pendidikan dan Pengajaran, Singaraja: LPTK Undiksha, vol. 45, no. 2, 2002.

[30] M. de Jong, R. Pieters and J. -Paul Fox, "Reducing Social Decirability Bias through Item Randomized Response: An Application to Measure Underreported Desires", Journal of Marketing Research, vol. 47, no. 1, pp. 14-17, 2010.

[31] R. McGrath, M. Mitchell, B. Kim. and L. Hough, "Evidence for Response Bias as A Source of error Variance in Applied Assessment", Psychological Bulletin, vol. 136, no. 3, pp. 456-472, 2000. 